\title{
European Union Policy on Refugees According to the International Refugee Law
}

\author{
Elisabeth Septin Puspoayu* \\ Department of Law, Faculty of Social \\ Sciences and Law \\ Universitas Negeri Surabaya \\ Surabaya, Indonesia \\ elisabethpuspoayu@unesa.ac.id
}

\author{
Hezron Sabar Rotua Tinambunan \\ Department of Law, Faculty of Social \\ Sciences and Law \\ Universitas Negeri Surabaya \\ Surabaya, Indonesia \\ hezrontinambunan@unesa.ac.id
}

\author{
Nurul Hikmah \\ Department of Law, Faculty of Social \\ Sciences and Law \\ Universitas Negeri Surabaya \\ Surabaya, Indonesia \\ nurulhikmah@unesa.ac.id
}

\begin{abstract}
This paper discusses the European Union (EU) as a supranational international organization which has the obligation to establish relevant rules in its organization, including the regulations on refugees. The existence of CEAS and its subordinate bodies is a form of reference for member countries of the $\mathrm{EU}$ in dealing with refugee issues. The exodus of refugees entering the European Union region, however, has made Italy, Greece, and Germany ignored and established domestic regulations regarding this refugee crisis. This stance has impacts on the refugees such as the presence of immigrant sentiments, surveillance in border areas, and refusal of refugees based on religion.
\end{abstract}

\section{Keywords: EU, refugees, international law}

\section{INTRODUCTION}

The European Union (EU) is a supranational organization [1], and countries in the EU are unique because their member states remain sovereign as well as independent, while at the same time, these countries are committed to integrating their sovereignty. It means that EU countries delegate their power in making decisions about several problems that occur in the European Union and in the interests of the European Union. The EU is an integrative body in certain fields, as stipulated in the European Constitution [1], that the European Union has certain authority over the States, the Maastricht Treaty which is the deed of establishment of the European Union does not regulate the juridical personality of the EU; it does not mean that the EU does not have juridical personality. As the subject of international law and a permanent organization, it will not lose its legal personality.

The European region has long been a major destination for refugees, especially refugees from the Middle East. With the increasing conflicts in the Middle East region have also resulted in the increasing number of waves of refugees entering Europe. The European region has a geographical proximity to the Middle East region, so that the refugees using ships are likely possible to reach the European region. Another factor is due to the stability of economy in the EU, which mainly becomes the attraction of many refugees to fleet to the EU countries.

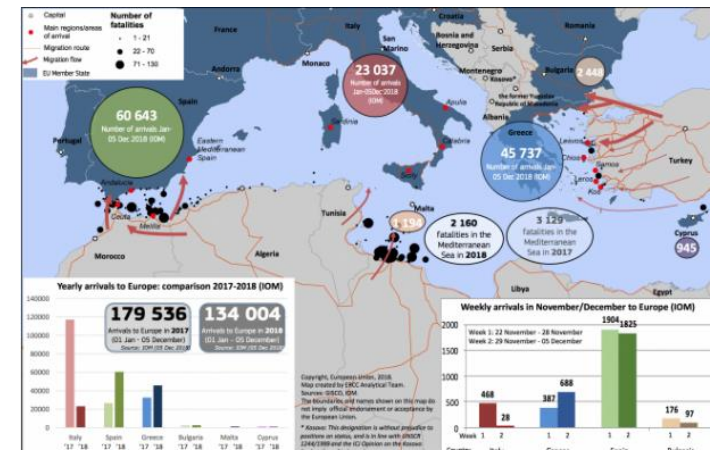

Source: www.undispatch.com[2]

The increasing number of refugees entering the European region eventually became the EU issued a policy to regulate the refugees, which is stipulated in the Common European Asylum System. This program aims to accommodate quickly and transparently the refugees who enter the EU region, and that their placement should be provided properly [3]; and it applies to refugees who are in danger as well.

As stated in the 1951 Refugee Convention, refugees are defined as people who are caused by reasonable fear due to any persecution based on their race, religion, nationality, membership in certain social groups and political parties outside their national state and do not want protection from that country [4]. The policy made by the EU is actually a form of compromise on the obligation to accept the refugees as well as the certain protection of their own citizens. However, the implementation of this policy was accepted differently by several countries in the EU. In June 2018 , Italy rejected the refugee boats [5]. The rejection happened continuously so that there were a number of refusal of refugee ships by Italian authority up to five times. Following is the timeline for the refusal of the refugee boats by Italian authority:

a. June $10^{\text {th }}, 2018$, Italy rejected the refugee boats carrying approximately 600 refugees when the ship was trying to dock at one port of Italy. The Aquarius boat was operated by an organization called Médecins Sans Frontières (MSF) or Doctors without Borders and the charity SOS Meditaranee [6];

b. June $10^{\text {th }}, 2018$, the boat was located 35 sea miles (about 65 kilometers) from Italy. MSF explained that on 
board of the Aquarius, there were 134 children without parents and seven women who were pregnant [6];

c. June $19^{\text {th }}, 2018$, Italian authority refused Diciotti boat carrying 522 refugees [7];

d. July $4^{\text {th }}$, 2018, Italy rejected the Open Arms boat carrying 60 refugees [6];

e. August $20^{\text {th }}, 2018$, Italy rejected the Diciotti boat carrying 177 refugees [3];

Rejection by a country to the refugees or returning the refugees is an act that is not in accordance with the principle of Non-Refoulement in the 1951 Refugee Convention, especially with regard to the status of refugees. It can also be categorized as an act of denial of the commitment of the international community to participate in contributing to the resolution of the refugee problem. Italy as one of the countries that has ratified the 1951 Refugee Convention is obliged to carry out its commitment as a country participating in the convention. Article 98 paragraph (1) of the 1982 United Nations Convention on the Law of the Sea of 1982 or the 1982 United Nations Convention of the Law of the Sea (hereinafter abbreviated to UNCLOS 1982) states that:

"Every State shall require the master of a ship flying its flag, in so far as he can do so without serious danger to the ship, the crew or the passengers:

(a) to render assistance to any person found at sea in danger of being lost;

(b) to proceed with all possible speed to the rescue of persons in distress, if informed of their need of assistance, in so far as such action may reasonably be expected of him;

(c) after a collision, to render assistance to the other ship, its crew and its passengers and, where possible, to inform the other ship of the name of his own ship, its port of registry and the nearest port at which it will call."

In the case of Italy's rejection, the refugees who were on the boats were in fact tired and did not have enough food supplies. Under Article 98 paragraph (1) of 1982 UNCLOS, rescuing people who have difficulties in such ships as soon as possible is an obligation for countries as subjects of international law. The rejection of the refugee boats has resulted in the floats of the refugee ships for several days at sea. The European Union Law has the main principle that asserts EU-sourced laws take precedence over domestic laws [8], so it cannot be justified if a member state makes such laws or other provisions which is contrary to the provisions of European Union Law. The legal superiority of the EU is a well-established principle [8]. From the issues elaborated above, it is interesting to discuss the juridical review of the policies by the EU on refugees according to the International Refugee Law.

\section{RESEARCH METHODS}

This is a normative juridical legal research [5], of which the method employed to collect legal material used is through literature study. Legal materials were derived from primary and secondary law sources in the form of primary legal materials referred to the provisions of international law, namely in the form of international conventions relevant to the issues under study. Secondary legal materials were obtained from literature, lecture materials, and other relevant books or works of international jurists who provide explanations related to the provisions of international law, particularly those are related to the European Union policies on refugees.

In this normative legal research, the legal materials that have been obtained were analyzed qualitatively through the provision of interpretation of the legal materials obtained from various sources. The analyses of the legal materials were assisted by using prescriptive method.

\section{RESULT AND DISCUSSION}

\section{A. INTERNATIONAL REFUGEE LAW}

The European Union is a form of supranational international organization that has rules agreed upon by the parties to the agreement. The 1951 Geneva Convention stipulates the obligation for countries which ratify this Convention to determine refugee status and make recommendations and rules regarding the welfare of the refugees including the availability of appropriate houses or settlement, education, and food distribution to the sense of security for the refugees residing in the region.

In the International Refugee Law, there are some parameters that can be used as to define the refugees as contained in article 1 (b) (2) of the 1951 Refugee Convention, namely:

a. Every person who left his country of citizenship or the country of origin of that person used to reside in search of a safe haven to another country because of the fear and anxiety that is very reasonable for acts of persecution against him.

b. A group of people who seek for safe havens in other countries. Refugees seek protection by crossing their borders to the borders of other countries because the refugees' country of origin cannot or are not willing to provide protection to the refugees.

A person can be said to be a refugee if he is forced to leave his home country as the country of origin does not have the ability or fails to guarantee the safety of these people. If the country of origin of the refugees can guarantee and provide protection, then it is certain that these people will not seek shelter to get guarantees for their rights to the territory of other countries.

The Non-Refoulement principle is to prohibit the participating countries of the Convention from returning or rejecting or placing refugees in situations that may threaten the safety and freedom of the refugees. This principle is as stipulated in the 1951 Refugee Convention on Refugee Status in Article 33. The principle of prohibiting expulsion in Article 33 is an obligation non-derogable based on humanitarian considerations. The UNHCR Executive Committee has determined that the Non-Refoulement principle is an improvement in peremptory norm in international law. Peremptory norm or called jus cogens is a basic principle of international law that has been accepted by countries as a basic norm that cannot be ignored. 
The Non-Refoulement principle is created for the common good and gives responsibility to all countries ratifying the 1951 Refugee Convention in order to fully implement the provisions of the Convention. If in the end non-refoulement is done to refugees, then several things that must be considered in advance are a very careful and detailed determination process based on a mature legal consideration. In addition, it must be ensured that when nonrefoulement is carried out, the relevant parties must also ensure that their presence in the third country is safe, their protection and freedom are fully guaranteed as it is the responsibility of a country for foreigners, especially refugees who are in the territory of their country, namely to treat humanely with due regard to humanity. [9]

Any expulsion of the refugees can only be executed if a decision has been issued with an adequate legal process. Refugees whom are suspected of threatening or disturbing national security are permitted to provide evidence that they do not threaten the national security such as demands made to clean themselves, and the refugees may appeal to the authorities. [10]

According to I Wayan Parthiana, there are several groups that are not allowed to get international protection or deserve to be punished if they are refugees, namely:

1. Military personnel from one or both parties who are at war;

2. Militia members who support one of the parties at war;

3. People who are members of a terrorist group;

4. People who have status as a prisoner of one or both countries at war and will be or are currently under his punishment in one of both parties at war or in a third country;

5. The persons suspected of committing one of four crimes that are subject to the criminal jurisdiction of the International Criminal Court (ICC), namely the crime of genocide, crimes against humanity, war crimes, and crimes against aggression (article 5 paragraph 1 of the Rome Statue in 1998)[9]

The people mentioned above can be included in the category of exclusion of the Non-Refoulement principle, while people who are not in the categories are prohibited from being expelled from the recipient country without any reasons related to national security and a strong legal basis.

In addition to the Non-Refoulement principle in International Refugee Law, there is also another principle of Responsibility to Protect, namely the protection of human rights which are the responsibility of a country in its implementation carried out without disturbing the country's sovereignty. The concept of Responsibility to Protect is very relevant to be applied and easily accepted by the international community compared to humanitarian intervention.

The UN Security Council also supports and recognizes the relevance of the principle of Responsibility to Protect. The UN has also produced the formulation of the principle of Responsibility to Protect into three main principles. First, the principle that each country has a responsibility to protect its citizens from genocide, war crimes, ethnic abolition, and crimes against humanity. Second, the principle which states that the commitment of the international community (i.e. members of the United Nations) to help countries protect their citizens from crimes against humanity. Third, the principle of the responsibility of every UN member states to respond or take appropriate action to prevent and stop crimes against humanity when a country fails to provide the intended human protection.

\section{B. IMPACTS OF POLICY ON REFUGEES IN THE EUROPEAN UNION}

The European Union as an international organization is obliged to guarantee the presence of refugees in the European Union territory. The US as a supranational international organization has the rights to enact rules for the countries that are affiliated to the organization. First is the Common European Asylum System (CEAS) which is the highest standard of the countries in the European Union region to deal with the issues related to refugees entering the EU region [11]. From this CEAS, the EU succeeded in establishing the European Refugee Fund which is used by the EU to regulate the input or donation of refugee funding and also the protection of refugees in the Temporary Protection Directive which is used in conducting data collection as well as reunions in the case there are refugees separated from their family members.

Second organization is the European Asylum Support Office (EASO) formed to protect and deal with issues related to the refugees in the European region. Unequal number of refugees in every country in the European region is under the responsibility of EASO. In handling its responsibility, EASO cooperates with countries of origin and third countries to relocate the refugees. This cooperation is conducted so that the refugees would get the appropriate treatment. In addition, issues related to the financial condition of the recipient country become the consideration for any relocation of the refugees. [8]

In the last 10 years, the EU has received at least $43.5 \%$ asylum requests from refugees worldwide. As an international organization that is also bound by the 1951 Refugee Convention, the EU must not refuse the coming of the refugees, for which the EU's duty is to protect anyone who needs protection, and this is stated in the Charter of Fundamental Right and Treaty on the Functioning of the European Union. [12]

The problems with asylum seekers who come to the EU every year is its uneven distribution in all EU member states. In 2013, $90 \%$ of asylum claims were only handled by 10 member countries. Sweden and Malta were the countries that have the highest number of applicants due to some factors, namely the location and welfare of the country, and also factor related to countries' favorable asylum policies. On this condition, the EU should take actions in terms solidarity among the country members to share the responsibilities for protecting the refugees in a dignified manner and ensuring they are treated fairly.

Such qualification of the status for the recipient of temporary protection is also included as the qualifications to improve the system of protection for the people who are not 
qualified as refugees; those people as recipients are who have substantial reasons that can be proven that if they are returned to their country of origin, they will face situations that can endanger themselves and not be able to or cannot afford the protection for themselves. This directive requires member states to give status to applicants who meet the requirements in accordance with the qualifications applied by the EU by seeing a series of protection rights from refoulement (refusal or return of the refugees or the asylum seekers to areas that could endanger their lives), residence permits, travel documents, access to work, access to education, social welfare, health services, and specific provisions for children and vulnerable people.

After CEAS was overhauled in 2013, the resulting directives are expected to contribute to improving the quality of decision-making in determining the qualifications of the asylum seekers who enter the EU territory. Dublin Regulation is a system that originally emerged as the Dublin Convention. Dublin Convention was adopted after the implementation of the Schengen Agreement which eliminates national borders in the European region. It is this situation where there are no boundaries between member countries that creates the needs to build strong harmonization in all aspects of policies within the European Union members, including the issue related to the asylum. Schengen allows incoming asylum seekers to move freely throughout Europe, and this is the reason why member states are expected to have joint responsibility in examining the asylum claims.

The Dublin Convention was later replaced by the Dublin Regulation II in 2003. The Dublin Regulation II retained the basic principles of the Dublin Convention, but in this regulation, it clarified the criteria for the responsibilities of all member states. The criteria in question were to ensure that all asylum claims entered were substantively examined to avoid recurring asylum shopping, where asylum seekers submit more than one applications to several member countries that were considered most likely to receive them or offer the most reception benefits; in this case, the country which was the first place of entry had full responsibility for handling the asylum claims as a whole. Other criteria were aimed at preventing any member states which did not accept or refuse to provide protection to the asylum seekers, this condition is called 'asylum seekers in orbit'. [12]

All member countries besides Denmark approved Dublin Regulation II, as well as non-member countries members of the Schengen zone such as Norway, Iceland, Switzerland, and Luxembourg. The Dublin Regulation II was later changed to Dublin regulation III in 2013. This was due to the emergence of criticism of the implementation of Dublin Regulation II which was considered unfair in distributing the responsibilities for handling the asylum applications. Dublin Regulation III was officially implemented in 2013 with two main objectives, namely (1) ensuring fast access to protection for anyone who needs it, and (2) increasing the efficiency of asylum procedures and reducing costs incurred by member countries by preventing asylum seekers from submitting multiple applications.
Dublin Regulation III establishes criteria for determining the responsibilities of member states in handling the asylum applications which must be applied in the hierarchic criteria, namely:

a. Family considerations. It prioritizes family unification and welfare of children who do not have any companions. Asylum seekers who have family members with refugee status or who are still in the process of applying for asylum will get their claim in the country where their core country is located. If an unaccompanied child has a family member in another member country, the member state is responsible for handling the child's claim. [10]

b. Legal residence permit or visa. In the case of asylum seekers who do not have a family, if they have a valid residence permit or visa, then their claim will be handled by the member country that issued the document.

c. Illegal Entry. If the applicant is not included in the aforementioned criteria, the applicant who does not have a family and a residence permit document, who illegally transits through several member countries when entering the EU territory, is the responsibility of the member country where he first came/entered.

d. Place of application. Finally, when someone does not meet the above criteria, the responsibility rests with the first member country where the applicant filed an asylum claim. Then the last is EURODAC Regulation which applies. [12]

All procedures established by the EU are the efforts of the EU as the supranational organization which is obliged to protect its member countries; this protection, however, is also problematic as many countries in the EU have established their own rules regarding the entry of refugees into the European region. The example of rejection of refugees by Italy could be based on the state's motto "Put Italian First!" This principle implies that Italy may not be obliged to accept the entry of the refugees into its territory. The rejection of the refugee boats from Syria is the evidence of the problematic domestic rules, which was then also followed by Malta and countries around Italy.

Several reactions emerge within member countries of the UE to the organization regarding the issue. Firstly, there is sentiment towards the issues related with refugees due to the unequal distribution of the number of refugees regulated by CEAS; many countries in the EU region are starting to restrict access to refugees by tightening borders with various reasons, in particular related to the threat and fear of terrorism which is at least imminent factor happening in the European Union. In 2015, Europol arrested 687 individuals suspected of terrorism. This report was based on checking the profiles of the suspects who are understood to have been affiliated with terrorist organizations outside the European Union [9]. 
Secondly, there is a policy regarding the handling of refugees whom are suspended by the European Union because the influx of the refugees is greater and makes the main EU policy on refugees unable to work. As the anticipation, many countries within the European Union enact regulations regarding these refugees separately with the EU as the bigger body. For example, Germany and Austria establish internal border controls to limit the entry of refugees; France controls refugees and immigrants widely to reduce crime rates. The application of internal border controls in member countries is based on legality in the Schengen Borders Code. Article 23 states "where there is a serious threat to public policy or internal security, a State Member may exceptionally reintroduce border control at its internal borders".

Thirdly, there is friction between Greece and other European Union countries. Greece is one of the countries in the EU which becomes the main gate for refugees entering the European Union. With this situation, Greece is considered to ignore the Dublin Declaration by not taking responsibility for conducting data collection and giving refugee status to the immigrants who entered the European Union. The case of Greece, which allowed the refugees to enter the region freely, was opposed by some member states. At a meeting of European Union Interior Ministers, representatives of Austria and Sweden who felt they had taken more refugees criticized Greece's actions to override the Dublin Regulation.

\section{CONCLUSION}

Corroborated the elaboration in the previous section, it can be concluded that the European Union must ensure that the Dublin Regulation is adhered to by the EU member states, and the EU must make it easier for admission from the refugees to the EU territory in accordance with the 1951 Refugee Convention.

\section{REFERENCES}

[1] Staff of EEAS Europa, "Sekilas Uni Eropa," Indonesia, 2017.

[2] NN, "Home UN Dispatch," 2018. [Online]. Available: https://www.undispatch.com/.

[3] Mark Leon Goldberg, "European Union Releases Facts and Figures for Migrant and Refugees
Arrivals in 2018," 2018. [Online]. Available: https://www.undispatch.com/european-unionreleases-facts-and-figures-for-migrant-and-refugeesarrivals-in-2018/. [Accessed: 11-Mar-2020].

[4] UNHCR, "Konvensi dan Protokol MENGENAI STATUS PENGUNGSI," Unhcr, p. 11, 1967.

[5] NN, "Italy Rejects for 1st Time Accepting Humanitarian Boat Carrying Over 600 Migrants News _ teleSUR English,” 2018. [Online]. Available:

https://www.telesurenglish.net/news/Italy-Rejectsfor-1st-Time-Accepting-Humanitarian-BoatCarrying-Over-600-Migrants-20180610-0010.html. [Accessed: 11-Mar-2020].

[6] G. Pianigiani, J. Horowitz, and R. Minder, "Italy's New Populist Government Turns Away Ship With 600 Migrants Aboard - The New York Times," The New York Times, new york, 11-Jun-2018.

[7] E. Moreatti, "Italy bars two more refugee ships from ports," the guardian, 2018. [Online]. Available: https://www.theguardian.com/world/2018/jun/16/ita ly-bars-two-more-refugee-ships-from-ports.

[Accessed: 11-Mar-2020].

[8] European Parliament, "Sources and scope of european union law," Fact sheets on the European Union, 2014. [Online]. Available: https://www.europarl.europa.eu/factsheets/en/sheet/ 6/sources-and-scope-of-european-union-law.

[9] I. wayan Parthiana, "Refugee and Extradition: Could a Refugee be Extradited?," J. Huk. Int., vol. 7, no. 4, pp. 670-694, 2010.

[10] L. A. Pertiwi, "Kompleksitas Rezim di Uni Eropa: Upaya Penanganan Pengungsi dan Pencari Suaka," J. Ilmu Sos. dan Ilmu Polit., vol. 19, no. 3, p. 218, 2016.

[11] K. Suriah et al., "TINJAUAN YURIDIS MENGENAI PERAN UNIEROPA TERHADAP PENGUNGSI DALAM KONFLIK TIMU TENGAH (studi kasus konflik suriah)," vol. 5, pp. 1-20, 2016.

[12] fitria Nurul R, "Implementasi Kebijakan Common European Asylum System Uni Eropa terhadap Krisis Pengungsi Eropa," UNIVERSITAS HASANUDDIN MAKASSAR, 2016. 